\title{
USING FOSSIL "FFINEERPRINTS" TO CIRCUMSCRIBE THE PALEOGEOGRAPHY OF TWO ALASKAN TERRANES ALONG THE URALIAN SEAWAY IN THE LATE SILURIAN
}

\author{
Anna I. Antoshkina ${ }^{1,2}$ and Constance M. Soja ${ }^{3}$ \\ ${ }^{1}$ Institute of Geology Komi SC of UB of RAS, Syktyvkar, Russia; antoshkina@geo.komisc.ru \\ ${ }^{2}$ Syktyvkar Pitirim Sorokin State University, Syktyvkar \\ ${ }^{3}$ Department of Geology, Colgate University, Hamilton, NY 13346 USA; csoja@colgate.edu
}

We present an updated model for the paleogeography of Alaska's Alexander and Farewell terranes, showing how a wealth of paleontologic and geologic data allow their locations to be circumscribed to the Northern Hemisphere-specifically the Uralian Seaway-in the Late Silurian. An unusually distinctive microbial-sponge-hydroid consortium constructed substantial platform-margin reefs in the terranes during the Late Silurian (Ludlow). The reefs and associated level-bottom communities exhibit strongest paleobiogeographic affinities with marine biotas found along the western and eastern slopes of the Urals and in Salair (southwestern Siberia). The microbe-dominated reefs are a Late Silurian «fingerprint» of abnormal Uralian Seaway conditions that were induced by a shrinking ocean basin, Caledonide tectonics, and related factors in the Late Silurian.

Keywords: unique reef biotas, Alexander and Farewell terranes, Urals, Siberia, Late Silurian paleogeography.

\section{ИСПОЛЬЗОВАНИЕ ОРГАНИЧЕСКИК ОСТАТКОВ-ИНДИКАТОРОВ ДЛЯ УТОЧНЕНИЯ ПАЛЕОГЕОГРАФИЧЕСКОГО ПОЛОЖЕНИЯ ДВУК ТЕРРЕЙНОВ АЛЯСКИ В ПРЕДЕЛАХ УРАЛЬСКОГО МОРСКОГО ПУТИ В ПОЗДНЕМ СИЛУРЕ}

\author{
А. И. Антошкина ${ }^{1,2}$, К. М. Соджа ${ }^{3}$ \\ ${ }^{1}$ Институт геологии Коми НЦ УрО РАН, Сыктывкар, Россия; antoshkina@geo.komisc.ru \\ ${ }^{2}$ Сыктывкарский государственный университет им. Питирима Сорокина, Сыктывкар \\ ${ }^{3}$ Геологический факультет Колгейтского университета, Гамильтон, Нью-Йорк, 13346, США; csoja@colgate.edu
}

\begin{abstract}
Мы представляем обновленную модель для палеогеографии террейнов Аляски - Александра и Фаревел, показывая, как многочисленные палеонтологические и геологические данные ограничивают их местоположение в позднем силуре северным полушарием, а именно в пределах Уральского морского пути. Чрезвычайно выразительный микробиально-губково-гидроидный консорциум формировал довольно мощные рифы на окраинах платформ террейнов в позднем силуре (лудлове). Рифы и связанные с ними придонные сообщества показывают самое тесное палеобиогеографическое сходство с морской биотой западного и восточного склонов Урала и Салаира (юго-западная Сибирь). Изобилующие микробиальными сообществами рифы являются своего рода позднесилурийской «дактилоскопией» аномальных условий Уральского морского пути, которые были вызваны сокращающимся океанским бассейном, каледонской тектоникой и связанными с ними факторами в позднем силуре.
\end{abstract} графия.

Ключевые слова: уникальная рифовая биота, террейны Александра и Фаревел, Урал, Сибирь, позднесилурийская палеогео-

\section{Introduction}

Diagnostic Silurian species found at disparate sites in the Northern Hemisphere can be used to constrain the paleogeographic setting of «exotic» terranes now located in western North America (Alaska), southwestern Siberia, and the Urals. Together with other geologic evidence, these data circumscribe terrane locations to the Uralian Seaway. Specifically, extensive microbial-sponge reef communities of Late Silurian (Ludlow) age occur in the Alexander terrane (AT) and Farewell terrane (FT) of Alaska, in Salair in southwestern Siberia, and along the western and eastern slopes of the Urals. These reefs were built by an unusually distinctive consortium of microbial organisms (calcified cyanobacteria, calcareous algae, and microproblematica), sphinctozoan (aphrosalpingid) sponges, and Fistulella, a problematic hydroid. They are found nowhere else in the world during that restricted time interval.

We present below a brief overview of Northern Hemisphere paleogeography, the geologic setting of the reef biotas, and their paleobiogeographic affinities. These data show that the microbe-dominated biotas record enormous ecological changes and unusual seaway conditions that prevailed across a broad region, bordered by Siberia to the north and by Laurentia and Baltica to the south [3, 53]. We hypothesize that narrowing of the Uralian Seaway and late-stage Caledonide (Scandian) tectonism generated significant terrestrial influx, reduced habitats for normalmarine metazoans, elevated nutrient loads, and, ultimately, fueled extensive microbial «blooms» that promoted stromatolite reef growth in the proto-Arctic basin in the Late Silurian.

\section{Northern Hemisphere Paleogeography}

Continents

In the Early-Mid Paleozoic, Laurentia and Baltica were clustered near the equator separated from Siberia to the north by the Uralian Seaway (Figure 1). During the 

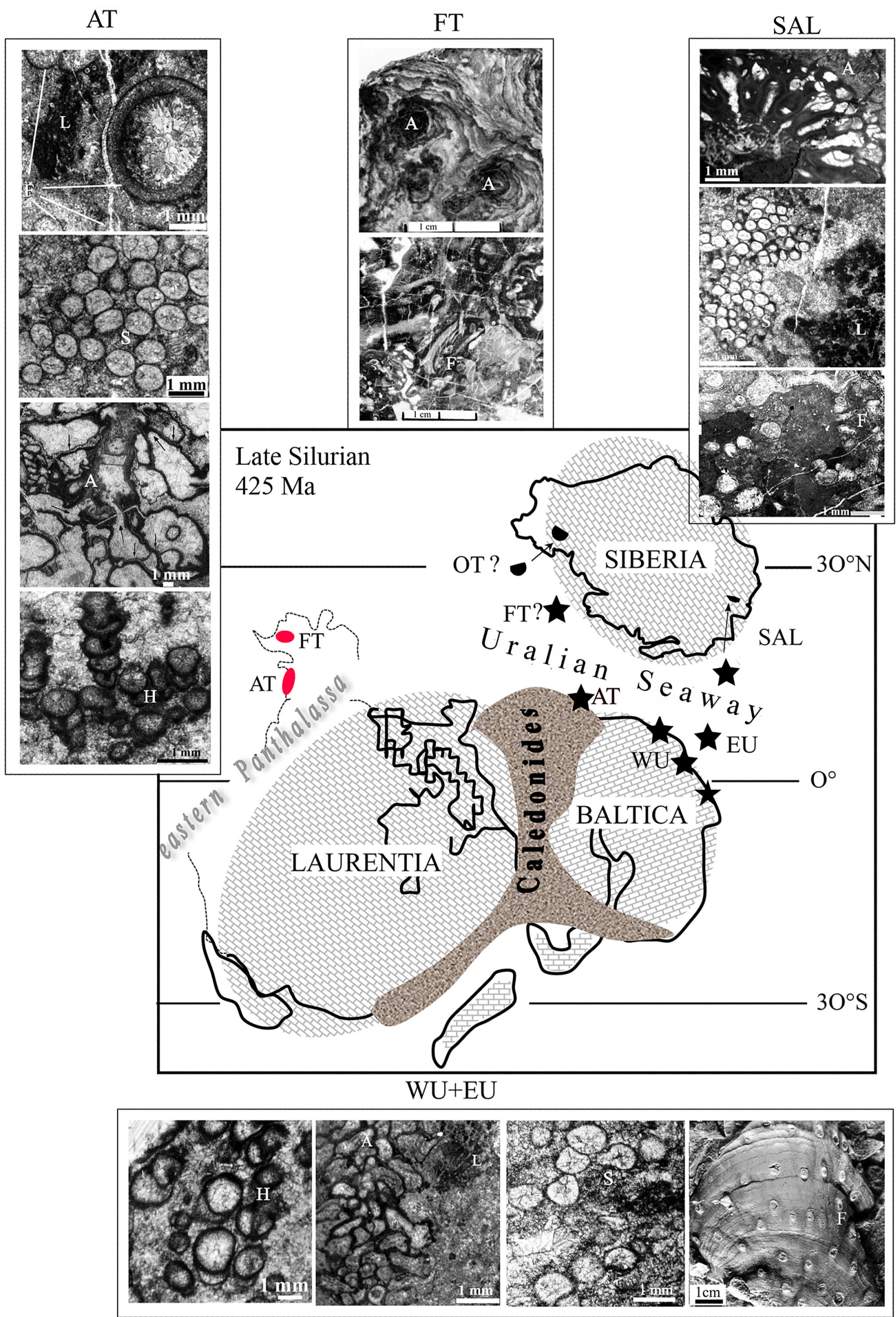

Figure 1. Our updated model for the paleogeography of Alaska's Alexander (AT) and Farewell (FT) terranes along the Uralian Seaway, which also shows current locations of the AT and FT in Alaska and photomicrographs of representative reef biotas (stars indicate sites of co-occuring microbial-sponge-hydroid reef associations in Alaska, Salair, and the Urals). Modified from [3, 20, 30, 50]. Abbreviations: EU-Eastern Urals; OT - Omulevka terrane, SAL - Salair, WU - Western Urals. Photomicrograph abbreviations: A - aphrosalpingids, F - Fistulella hydroid, H - Hecetaphyton, L - Ludlovia, S - Sphaerina 
Silurian, that seaway straddled the equator and was at its narrowest [30] with Siberia in close proximity to Baltica [19]. In the Late Silurian, Laurentia and Baltica collided during culminating phases of the Caledonide Orogeny. As Euramerica (Laurussia) was being consolidated, flyschmolasse sequences of the Old Red Sandstone (ORS) developed across $40^{\circ}$ of latitude, extending $4500 \mathrm{~km}$ from eastern North America to Ireland, the UK, Norway, East Greenland, and Spitsbergen. The extraordinary thickness $(4-8 \mathrm{~km})$ of ORS sequences reflects high depositional rates in rapidly subsiding, intra-montane basins $[9,10,19$, $21,25]$.

Until the onset of Uralide orogenesis, eastern Baltica (western slope of the present-day Ural Mountains) was a passive continental margin and unaffected by Caledonide orogenesis, as indicated by the absence of red bed molasse in the Late Silurian-Early Devonian. The Tagil and other volcanic arcs were accreted as terranes to Baltica, forming the eastern slope of the Urals beginning in the Late Devonian [36]. However, the pre-Carboniferous location of specific arc terranes that underwent accretion during the Uralide orogen is still debated.

\section{Terranes}

The Alexander terrane $(A T)$ is one of the largest and best studied of the many terranes that form the North American Cordillera (all references in [50]). It originated in the Neoproterozoic-Early Paleozoic as an island arc and comprises early Precambrian detrital zircons that match the age of magmatic rocks found only in Baltica [26, 32]. Moreover, the Wales pre-Ordovician orogenic event in the AT bears similarities with the Neoproterozoic-early Paleozoic Timanide orogen of eastern-northeastern Baltica [20]. Significantly, the AT is the only Cordilleran terrane that experienced a Late Silurian-Early Devonian orogeny (Klakas event); detrital zircons extracted from orogenic molasse (Upper SilurianLower Devonian Karheen Formation) best match those from western Baltica and the northern Caledonides [12, 13, 20, 26]. Finally, Silurian-Lower Devonian facies in the AT are very similar lithologically to coeval ORS deposits, which suggest that the arc-continent collision experienced by the AT during the Klakas event was related to Caledonide orogenesis [11-13, 55, 58]. Because its geologic history and fossil affinities are well established, the AT's location along the mid-southern portion of the Uralian Seaway (Figure 1) serves as a linchpin for unraveling Northern Hemisphere paleogeography in the midPaleozoic, as described below.

The Farewell terrane (FT) of southwestern Alaska is a continental margin fragment, as indicated by Lower Paleozoic carbonate and siliciclastic shelf and slope deposits [20]. Early Paleozoic faunas share affinities with biotas in Siberia as well as Laurentia, Arctic Alaska-Chukotka terrane, and, to a lesser extent, the Omulevka terrane. This suggests that the terrane was derived from the Siberian (or Laurentian?) margin [14, 57]. Even though its mid-Paleozoic paleolatitude has yet to be established from paleomagnetic data, the FT was most likely located within $30^{\circ}$ of the equator, given the thick carbonate deposits and abundance of warm-water indicators.

Debates persist about whether Salair, a Neoproterozoic-Early Paleozoic island arc, accreted to southwestern Siberia (present-day coordinates) in the early
Ordovician, subsequently forming part of a passive continental margin sequence, or if it remained an independent tectonic entity (micro-continent) before becoming welded to Siberia in the post-Silurian [23, 31, 60]. Thus, Salair's paleogeography in the Late Silurian-Early Devonian remains open for discussion, although paleomagnetic data locate it within $30^{\circ}$ of the equator in the mid-Paleozoic [59], as does paleontologic and sedimentologic evidence (discussed below).

\section{Late Silurian Microbial Reefs}

The AT is one of two Cordilleran terranes where an unusually distinctive consortium of microbial organisms (calcified cyanobacteria, calcareous algae, and microproblematica), sphinctozoan (aphrosalpingid) sponges, and Fistulella (a problematic hydroid) built enormous reefs in the Late Silurian (Ludlow) (Table 1). These microbe-dominated deposits do not represent level-bottom mat communities that grew in a marginal-marine or intertidal setting, as suggested by Cocks and Torsvik [19]. Rather, associated metazoans, the massiveness of the limestones, and the downslope deposition of megabreccias - some in the AT comprise house-sized blocks lithified by coarse rinds of marine carbonate cements - clearly indicate that the calci-microbes constructed substantial stromatolite reefs at a platform margin [7, 45, 47, 56].

The FT is the other Cordilleran terrane where an extensive microbial reef complex developed in the Late Silurian-Early Devonian [18]. Diverse microbial taxa (e. g., Solenopora, Epiphyton, Renalcis, and Sphaerocodium) constructed the buildups associated with dasycladaceans, gypidulinid brachiopods, sphinctozoan sponges (aphrosalpingids), problematic hydroids (e. g., Fistulella), and rare corals and stromatoporoids. These deposits are approximately $500 \mathrm{~m}$ thick, $1 \mathrm{~km}$ wide, and several $100 \mathrm{~km}$ long. They interfinger with limestone debris flows and graptolitic shales of basinal origin.

The Ludlow reefs of the Urals formed in two different environmental settings: A) the West-Uralian reefs exposed for $2500 \mathrm{~km}$ were rigid organic structures that grew a passive platform at the eastern margin of Baltica; B) reefal limestones from the Eastern Urals originated in the Tagil island arc during a phase of waning volcanism. The Ludlow reefs are characterized by a similar, distinctive stromatolitic framework, encrustations of aphrosalpingid sponges on Fistulella $[6,7,53]$, and relatively rare, fragmented remains of shelly marine benthos (brachiopods, coral, etc.) (Figure 1). In the Upper Silurian reefs of both regions, similar groups of organisms comprise the major reef-builders and reef-dwellers (Table 1). The co-occurrence of Aphrosalpinx textilis, Fistulella undosa, and Ludlovia multispora establishes a paleobiogeographic link between WestUralian and East-Uralian environmental settings during the Late Silurian.

In northwestern Salair, Ludlow reefs described from the Potapovka Formation also exhibit a relatively low abundance of metazoans in a reef framework dominated by a similar consortium of microbial-stromatolitic taxa [3, 4].

\section{Paleoenvironmental and Paleogeographic Implications}

Because the AT's location is circumscribed to the Caledonide region in the Late Silurian-Early Devonian, 
the AT's distinctive biotas shed insights into paleoenvironmental conditions and paleogeographic relations that once existed in the proto-Arctic basin. In the Late Silurian, the Uralian Seaway was a narrow, equatorialsubequatorial marine corridor affected by Caledonide orogenesis along its southern margin $[19,50]$. As the orogenic event reached its peak in the Late Silurian (Scandian phase), vast accumulations of Caledonide-derived sediment poured into the Uralian Seaway. Terrigenous sediment filled deep-marine troughs before flooding across shallow-marine platforms, terminating carbonate deposition to the south $[19,25]$. We hypothesize that excessive nutrients, transported via terrigenous clastic runoff, fueled cyanobacterial «blooms» [50]. Unusual seawater chemistry and fluctuations in temperature, salinity, and oxygen concentrations could have also induced stressed environmental conditions [49].

The AT's microbial reefs, which existed for a short time during culminating Caledonide (Scandian) phases in the Ludlow, clearly serve as a «fingerprint» of abnormal marine conditions that developed in the Uralian Seaway in the Late Silurian. Thus, we propose that similar, coeval biotas, such as those from the FT, Urals, and Salair, must have evolved at sites within that broad but contiguous marine basin, where Uralian Seaway conditions were conducive to the expansion of microbe-dominated communities. Percentages of taxa shared in common among coeval biotas are used to help locate more precisely each reef site and thus refine Northern Hemisphere paleogeography in the mid-Paleozoic.

Although not identical in taxonomic composition, the Alaskan reefs are most similar to coeval stromatolitesponge-hydroid reefs that developed in eastern Baltica [2, $7,8,47,48]$. The Uralian microbial reefs share $>80 \%$ of key taxa in common with the AT reefs (Table 1). Ludlow reefs in Salair also exhibit greatest similarities with the Uralian and AT reefs, sharing $61 \%$ of taxa in common; far fewer of the reef taxa $(22 \%)$ co-occur in the FT [3, 4, 7] (Table 1). Similarly, the Ludlow microbial reefs in the AT and the Urals share only 25-30\% of taxa in common with the FT [48] (Table 1).

The paleontologic data indicate that Salair must have existed within the Uralian Seaway at a site between Baltica and Siberia that favored biotic exchange with the Tagil (EU) and Salair island arcs, AT, and, to a lesser extent, the FT in the Late Silurian (Figure 1). The greater similarities shared with the Uralian and AT biotas suggest that Salair was most likely located in the eastern portion of the seaway, either as an independent micro-continent or as part of southwestern Siberia (Table 1, Figure 1).

Because the FT shares some Ludlow reef biotas in common with Salair, the AT, and Urals, it too must have been located along the Uralian Seaway somewhere between Siberia, Baltica, Laurentia, and the AT [20, 50]. However, the absence of post-orogenic, flysch-molasse sequences in the FT comparable to the ORS indicates that the FT was not affected by the Caledonide orogeny and so must have resided at a significant distance from the orogenic front. Also, given the lower percentage of Silurian biotas in the FT that co-occur in the AT and Urals, the FT was most likely located along the northern margins of the Uralian Seaway at a site that lay beyond the effects of Caledonide tectonism and molasse deposition in the Late Silurian [49] (Table 1, Figure 1).
Additional support for our paleogeographic model is derived from a comprehensive compilation of all Silurian taxa described to date from the AT-from microbes to metazoans associated with reefs and level-bottom habitats (Table 1). Those data reveal that Silurian biotas in the AT do indeed exhibit strongest provincial affinities with Baltica, sharing $61 \%$ in common. Significantly fewer AT taxa co-occur elsewhere, as indicated by the $20 \%$ of taxa shared with Laurentia, $16 \%$ with Salair, $12 \%$ with the eastern Urals, and $11 \%$ with the FT and also Siberia (Table 1). Thus, the paleontologic evidence is in full agreement with paleogeographic data derived from paleomagnetic and detrital zircon studies, which position the AT close to the Caledonide front $[11-13,20]$.

This multi-disciplinary perspective helps explain how similar Late Silurian marine communities could evolve in disparate tectonic settings: island arcs (AT, EU), passive continental margin (WU), and micro-continents (Salair, FT). Clearly, organisms that colonized those areas were adapted to the special conditions that arose during culminating phases of the Caledonide orogeny, as marine habitats were shrinking and receiving considerable sediment influx. Each biota acquired its own regional signature but was able to exchange larvae and undergo transmigration with other sites within the Uralian Seaway. Those in closer physical proximity or linked via effective ocean currents are characterized by a higher percentage of taxa shared in common (Figure 1).

During culminating orogenic phases in the Late Silurian-Early Devonian, the AT reefs collapsed as the shelf margin foundered, and AT biotas experienced regional extinction during marine regression and molasse progradation [55]. Elsewhere, however, abnormal conditions appear to have prevailed for millions of years at sites along the Uralian Seaway not overwhelmed by Caledonide-derived clastic influx. In particular, microbial-dominated reefs, associated in many areas with Fistulella, persisted into the Early Devonian along the western slope of the Urals, in the Tagil volcanic arc that would be accreted later to form the eastern Urals, and in the FT [5, 18]. The prolonged existence of massive reefs with a stromatolite-like, calcified framework, atypical for most Paleozoic reefs, is testament to the prevalence of unusual environmental conditions within the Uralian Seaway over a considerable interval of time $[1,2]$.

Finally, to test the hypothesis that the microbialaphrosalpingid-Fistulella reefs are a Late Silurian «fingerprint» for abnormal Uralian Seaway conditions in the Late Silurian, research was undertaken on coeval limestone deposits that formed in the Gobi-Altaj and Mandalovoo terranes in Mongolia. Those terranes were situated in the Northern Hemisphere within $35^{\circ}$ of the paleoequator but beyond the eastern margin of the Uralian Seaway in the Paleozoic [35, 52]. The coeval rocks examined in Mongolia formed under environmental conditions broadly similar to those in the AT (i. e., in a spectrum of shallow- to deep-marine, limestone-dominated environments in a tectonically active setting). Yet calci-microbes do not predominate in the reefs or level-bottom communities there, and none of the distinctive microbial, aphrosalpingid, or hydroid taxa exist in the Gobi-Altai region [35, 52]. This helps confirm our hypothesis that unusual conditions along the Uralian Seaway-and nowhere else-favored the development of microbial reefs in the Late Silurian. 
Table 1

Compilation of all key Silurian taxa described from the AT, their distribution in other sites, and their paleobiogeographic affinities, as indicated by the authors of the references shown

\begin{tabular}{|c|c|c|c|c|c|c|c|c|c|c|c|c|c|c|c|c|c|}
\hline FORMATION & SILURIAN TAXA (in AT) & Authors (see references) interpret to be most like species from -> & BAL & LAU & SAL & EAS & FAR & SIB & OT & WNA & AER & LIV & AT & $\cos$ & IND & Affinities interpreted as & As reported in \\
\hline & & $\begin{array}{c}\text { authors' additional notes } \\
\end{array}$ & & & & & & & & & & & endemic & & & & \\
\hline & Level-bottom taxa are in white boxes & & & & & & & & & & & & & & & & \\
\hline & Microbial reef taxa are in orange boxes & & & & & & & & & & & & & & & & \\
\hline \multirow{14}{*}{ Heceta } & & & & & & & & & & & & & & & & & \\
\hline & $\begin{array}{l}\text { KEY BRACHIOPODS (N=13) } \\
\text { Brooksina alaskensis }\end{array}$ & & & & & & & & & & & & & & & & \\
\hline & Brooksina alaskensis & & $\mathbf{X}$ & $\mathbf{X}$ & & $\mathbf{X}$ & & & $\mathbf{X}$ & & & & & & & Uralian-Cordilleran subprovince & {$[14,27,42,43]$} \\
\hline & Kirkidium vogulicum & possible AT occurrence of morph. variable species* & $\mathbf{X}$ & $\mathbf{X}$ & & $\mathbf{X}$ & & & & & & & & & & (of Old World province) & {$[* 14$, pg. 327] } \\
\hline & Kirkidium cf. alaskense & & & & & & & & $\mathbf{x}$ & & & & & & & 1 & 1 \\
\hline & Harpidium insignis & & $\mathbf{X}$ & & & $\mathbf{X}$ & & & $\mathbf{X}$ & & & & & & & 1 & 1 \\
\hline & Conchidium cf. alaskense & & & $\mathbf{X}$ & & & & & $\mathbf{X}$ & & & & & & & 1 & 1 \\
\hline & Nanukidium cf. N. cunninghamensis & & & $\mathbf{X}$ & & & & & & & & & & & & 1 & I \\
\hline & Atrypoidea borealis & genus is widespread globally (Sil), common in Arctic Canada & & & & $\mathbf{X}$ & & & $\mathbf{X}$ & & & & & $\mathbf{X}$ & & 1 & {$[28,33]$} \\
\hline & & & & & & & & & & & & & & & & 1 & 1 \\
\hline & Gracianella & genus is widespread globally in Silurian & $\mathbf{X}$ & $\mathbf{X}$ & & $\mathbf{X}$ & & & & & & & & $\mathbf{X}$ & & $\mathrm{V}$ & [33] \\
\hline & Alaskospira dunbari & & & & & & & & & & & & & & & & [16] \\
\hline & Cymbidium acutum & & & $\mathbf{X}$ & & & & & & & & & & & & & 1 \\
\hline & Atrypoidea tenuis & & & & & & & & & & & & & & & & $\mathrm{V}$ \\
\hline Willoughby & Sapelnikoviella santuccii & new genus \& species & & & & & & & & & & & $\mathbf{X}$ & & & & {$[15]$} \\
\hline SIL/unknown & Strophatrypa skaflestadi & new genus \& species & & & & & & & & & & & $\mathbf{x}$ & & & & {$[17]$} \\
\hline \multirow{2}{*}{\multicolumn{18}{|c|}{$\begin{array}{l}\text { (Kennel Creek } \\
\text { see [29]) }\end{array}$}} \\
\hline & & & & & & & & & & & & & & & & & \\
\hline \\
\hline & & & & & & & & & & & & & & & & & \\
\hline \multirow{25}{*}{ (\& Willoughby) } & Bathmopterus liratus & endemic genus \& species & & & & & & & & & & & $\mathbf{X}$ & & & & {$[14,24,40]$} \\
\hline & Beraunia bohemica & species occurs in Late Silurian of Bohemia & $\mathbf{X}$ & & & & & & & & & & & & & & 1 \\
\hline & Beraunia bifrons & appears identical to species from Late Silurian, Bohemia & $\mathbf{X}$ & & & & & & & & & & & & & & 1 \\
\hline & Hecetastoma gehrelsi & new genus \& species & & & & & & & & & & & $\mathbf{X}$ & & & & \\
\hline & Coelocaulus karlae & resembles some Silurian species of Coelocaulus from & $\mathbf{X}$ & & & & & & & & & & & & & & I \\
\hline & & Prague Basin; genus is known from eastern NA (mid-late Sil) & & & & & & & & & & & & & & & 1 \\
\hline & Baichtalia tongassensis & new genus \& species & & & & & & & & & & & $\mathbf{X}$ & & & & I \\
\hline & Kirkospira glacialis & new genus \& species; similar to "Pleurotomaria" & $\mathbf{X}$ & & & & & & & & & & & & & & 1 \\
\hline & & lindströmi from Urals; genus is known from eastern NA & & & & & & & & & & & & & & & 1 \\
\hline & Goniostropha & & $\mathbf{X}$ & & & & & & & & & & & & & & {$[14]$} \\
\hline & Medfracaulus turriformis & appears identical to $M$. turriformis from the Urals & $\mathbf{X}$ & & & $\mathbf{x}$ & $\mathbf{x}$ & & & & & & & & & & 1 \\
\hline & & (+ genus is known from SIB $)$ & & & & & & $\mathbf{x}$ & & & & & & & & & I \\
\hline & Pachystrophia gotlandica & Euomphalus gotlandicus from Wenlock of Gotland is & $\mathbf{X}$ & & & & (X) & & & $\mathbf{x}$ & & & & & & & I \\
\hline & & very similar in size and shape & & & & & & & & & & & & & & & I \\
\hline & Retispira aff. $R$. volgulica & very similar in size, shape, ornament to Ludlow & $\mathbf{X}$ & & & & & & & & & & & & & & 1 \\
\hline & & "Bellerophon" volgulicus from Urals & & & & & & & & & & & & & & & 1 \\
\hline & Pachystrophia cf. gotlandica & (+ genus is known from Gondwana terrane) & $\mathbf{X}$ & & & & & & & & & & & & & close relationship with gastropod & [41] \\
\hline & Spinicharybdis krizi & genus is known from the E Sil (Gotland) \& Late Silurian & $\mathbf{X}$ & $\mathbf{X}$ & & & & & & & & & & & & faunas of Bohemia \& FAR & [33] \\
\hline & Spinicharybdis boucoti & (Ludlow) of Canadian Arctic (+ Kazakhstan) & & $\mathbf{X}$ & & & & & & & & & & & & 1 & 1 \\
\hline & Haplospira craigi & H. spinosum from the Silurian (Ludlovian) Kopanina Fm & $\mathbf{X}$ & & & & & & & & & & & & & I & I \\
\hline & & of Czech Republic & & & & & & & & & & & & & & 1 & 1 \\
\hline & Australonema sp. & Gotland; Siberia (Sil); Bohemia (Dev); Australia (Dev) & $\mathbf{X}$ & & & & & $\mathbf{X}$ & & & & & & & & 1 & I \\
\hline & Morania wagneri & Bohemia, Scotland, eastern Canada & $\mathbf{X}$ & $\mathbf{X}$ & & & & & & & & & & & & 1 & I \\
\hline & Morania nixonforkensis & (genus is known from SIB + Gondwana terrane) & & & & & $\mathbf{X}$ & $\mathbf{X}$ & & & & & & & & 1 & I \\
\hline & Medfrazyga gilmulli & Medfrazyga clauticae from Dev of southwestern AK & & & & & $\mathbf{x}$ & & & & & & & & & $\mathrm{V}$ & $\mathrm{V}$ \\
\hline
\end{tabular}


Table 1 continuation

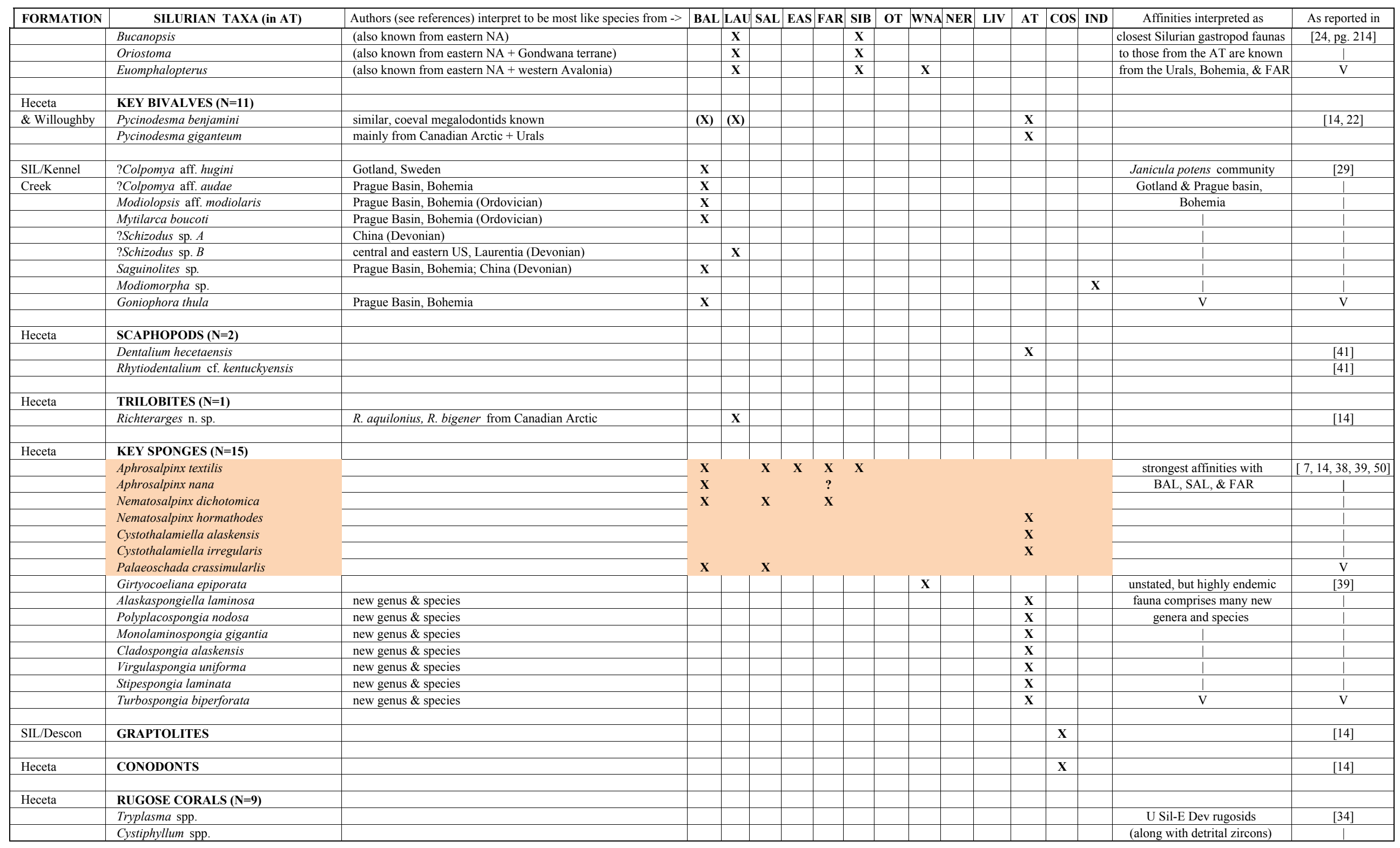


Table 1 continuation

\begin{tabular}{|c|c|c|c|c|c|c|c|c|c|c|c|c|c|c|c|c|}
\hline \multirow{2}{*}{\begin{tabular}{|l|l|} 
FORMATION \\
\end{tabular}} & \multirow{2}{*}{\begin{tabular}{|l|} 
SILURIAN TAXA (in AT) \\
new cystiphyllid
\end{tabular}} & \multirow{2}{*}{ Authors (see references) interpret to be most like species from -> } & \multicolumn{2}{|c|}{ BAL $\mathbf{L A U}$} & SAL & \multicolumn{3}{|c|}{\begin{tabular}{|l|l|l|} 
EAS & FAR & SIB \\
\end{tabular}} & \multirow[t]{2}{*}{ OT } & WNA NER & \multirow[t]{2}{*}{ LIV } & \multirow[t]{2}{*}{ AT } & \multirow[t]{2}{*}{$\cos$} & \multirow[t]{2}{*}{ IND } & \multirow{2}{*}{$\begin{array}{c}\text { Affinities interpreted as } \\
\text { indicate the AT was in }\end{array}$} & As reported in \\
\hline & & & & & & & & & & & & & & & & \\
\hline & Microplasma sp. & & & & & & & & & & & & & & the northern hemisphere at & \\
\hline & Rhizophyllum sp. A & & & & & & & & & & & & & & longitude near BAL and in Late & \\
\hline & Zelophyllum sp. & & & & & & & & & & & & & & Devonian-Early Carboniferous & \\
\hline & Plasmophyllum labrum $\mathrm{n} . \mathrm{sp}$. & & & & & & & & & & & $\mathbf{x}$ & & & was close to w. Canada & \\
\hline & Plasmophyllum sp. & & $\mathbf{x}$ & & & & & $\mathbf{x}$ & & & & & & & 1 & 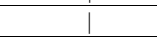 \\
\hline & new kyphophyllids & & & & & & & & & & & & & & $\mathrm{V}$ & $\mathrm{V}$ \\
\hline & & & & & & & & & & & & & & & & \\
\hline Heceta & ?HYDROID (N=1) & & & & & & & & & & & & & & & \\
\hline \& Willoughby & Fistulella undosa & & $\mathbf{x}$ & & $\mathbf{x}$ & $\mathbf{x}$ & $\mathbf{x}$ & & & & & & & & & {$[2,3,7,53]$} \\
\hline & & & & & & & & & & & & & & & & \\
\hline Heceta & MICROBIOTAS (N=14) & & & & & & & & & & & & & & & \\
\hline \multirow[t]{14}{*}{ \& Willoughby } & Girvanella problematica & & $\mathbf{x}$ & & $\mathbf{x}$ & & & & & & & & & & strongest affinities with & {$[37,54]$} \\
\hline & Girvanella sp. & & & & & & - & & & & & & & & BAL, SAL, \& FAR & {$[3,7,50]$} \\
\hline & Hedstroemi a sp. & & $\mathbf{x}$ & & $\mathbf{x}$ & & & & & & & & & & 1 & 1 \\
\hline & Epiphyto $\mathrm{n}$ sp. & & $\mathbf{x}$ & $\mathbf{x}$ & $\mathbf{x}$ & & $\mathbf{x}$ & & & & & & & & $\frac{1}{1}$ & $\frac{1}{1}$ \\
\hline & Hecetaphyton alaskense & new genus \& species & $\mathbf{x}$ & & $\mathbf{x}$ & & & & & & & & & & 1 & 1 \\
\hline & Ludlovia multispora & & $\mathbf{x}$ & & $\mathbf{x}$ & $\mathbf{x}$ & & & & & & & & & i & [42] \\
\hline & Renalcis $\mathrm{cf}$. R. tuberculatus & & $\mathbf{x}$ & & $\mathbf{X}$ & & $\mathbf{x}$ & & & & & & & & 1 & 1 \\
\hline & "Solenopora" compacta & & $\mathbf{x}$ & & & & & & & & & & & & 1 & 1 \\
\hline & "Solenopora" filiformis & & $\mathbf{X}$ & & & & & & & & & & & & i & \\
\hline & "Solenopora" gotlandica & & $\mathbf{x}$ & & & & & & & & & & & & 1 & 1 \\
\hline & Rothpletzella gotlandica & & $\mathbf{x}$ & & & & & & & & & & & & 1 & I \\
\hline & Tuxekanella simplex & new genus \& species & $\mathbf{x}$ & & & & & & & & & & & & 1 & [44] \\
\hline & Wetheredella silurica & & $\mathbf{x}$ & & $\mathbf{x}$ & & & & & & & & & & 1 & 1 \\
\hline & Sphaerina congregata & new genus \& species & $\mathbf{x}$ & & $\mathbf{x}$ & & & & & & & & & & $\mathrm{V}$ & $\mathrm{V}$ \\
\hline & & & & & & & & & & & & & & & & \\
\hline \multirow[t]{9}{*}{ Heceta } & ICHNOGENERA (N=5) & & & & & & & & & & & & & & & \\
\hline & Chondrites ichnosp. & & & & & & & & & & & & & $\mathbf{X}$ & none suggested & [46] \\
\hline & ?Chondrites ichnosp. & & & & & & & & & & & & & $\mathbf{X}$ & 1 & 1 \\
\hline & Palaeophycus ichnosp. & & & & & & & & & & & & & $\mathbf{X}$ & $\frac{1}{1}$ & 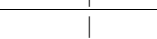 \\
\hline & Planolites ichnosp. cf. P. beverleyensis & & & & & & & & & & & & & $\mathbf{X}$ & 1 & 1 \\
\hline & ?Planolites ichnosp. & & & & & & & & & & & & & $\mathbf{X}$ & $\mathrm{V}$ & $\mathrm{V}$ \\
\hline & OUALITATIVE TALLY & & 42 & 15 & 12 & 9 & 8 & & 5 & 3 & 0 & 19 & 4 & 6 & & \\
\hline & note: after completing compilation, columr & were re-arranged to show strongest to weakest faunal affinities from & $n$ left to & o right & & & & & & & & & & & & \\
\hline & & & & & & & & & & & & & & & & \\
\hline \multicolumn{17}{|c|}{ TOTAL \# AT TA93 } \\
\hline \multicolumn{17}{|c|}{ Total \# AT enden 19} \\
\hline \multirow{3}{*}{\multicolumn{3}{|c|}{$\begin{array}{l}10 t a \text { A AT non- } 6 / 4 \\
\% \text { of } 74 \text { non-endemic AT taxa found in other geographic sites -> }\end{array}$}} & & & & & & & & & & ademic & cs $=$ & & & \\
\hline & & & 61 & 20 & 16 & 12 & 111 & 11 & 7 & 40 & 0 & $20 \%$ & 5 & 8 & & \\
\hline & & & BAL & $|\mathbf{L A U}|$ & SAL & EAS $\mid$ & FAR $\mid \mathbf{S}$ & SIB & OT 1 & WNA NER & LIV & AT & $\cos \mid$ & IND & & \\
\hline breviations: $\mathbf{A}$ & T (Alexander terrane); BAL (Baltica); C & Ut & & na d $K$ & Kon & shof 200 & 008); FA] & $\mathbf{A R}$ & arewel & ell terrane of sc & southy & estern $t$ & Alaska) & a); & & \\
\hline
\end{tabular}




\section{Conclusions}

Our updated paleogeographic reconstruction of the Northern Hemisphere in the Late Silurian is based on an analysis of unique reef biotas and associated communities described from the AT, FT, Salair, and Urals. Those reefs, dominated by microbial rather than metazoan taxa, are diagnostic indicators of the stressed environmental conditions that developed along the Uralian Seaway in the Late Silurian during culminating phases in the Caledonide orogeny. An integration of paleogeographic (paleomagnetic, detrital zircon) and paleobiogeographic (paleontologic) evidence allows the AT to serve as a linchpin for identifying the Northern Hemisphere position of some accreted terranes and micro-continents in the mid-Paleozoic.

\section{Acknowledgments}

We are grateful to the National Science Foundation of USA and to many colleagues at Colgate University, Smith College, Institute of Geology (Syktyvkar), Institute of Geology and Geophysics (Ekaterinburg), Kuzbass State Pedagogical Academy (Novokuznetsk), and Mongolian University of Science and Technology (Ulaanbaatar) who provided support, help, guidance, and advice in the field. Additional thanks go to Viktor N. Puchkov for constructive comments on a final version of this paper.

\section{References}

1. Antoshkina A. I. 1998. Organic buildups and reefs on the Palaeozoic carbonate platform margin, Pechora Urals, Russia. Sedimentary Geology, V. 108 (1-4), pp. 187-210.

2. Antoshkina A. I. 2003. Rifoobrazovanie $v$ Paleozoe (Sever Urala i sopredelnye oblasti) (Reef formation in Paleozoic (Northern Urals and adjacent areas)) UrO RAN, Ekaterinburg. 303 pp.

3. Antoshkina A. I. 2005. Rifovaya biota Urala i Salaira: Paleobiogeograficheskoe znachenie dlya srednego Paleozoya (Reef biota of Urals and Salair: Paleobiogeographical value for Middle Paleozoic). Komi Nauchnyj Tsentr, Uralskoe Otdelenie, Rossijskaya akademiya nauk. Nauchnye doklady. V. 469, pp. 1-26.

4. Antoshkina A. I., Gutak Y. M., Bagmet G. N., and Savistkij V. R. 2006. Novye dannye po silurijskim rifam Salaira, Zapadnaya Sibir (New data on Silurian reef of Salair, Western Siberia). Novosti Paleontologii i Stratigrafii. V. 9, pp. 21-29.

5. Antoshkina A. I., Königshof P. 2008. Lower Devonian reef structures in Russia: an example from the Urals. Facies. V. 54, pp. 233-251.

6. Antoshkina A. I., Soja C. M. 2000. Ekologicheskie osobennosti pozdnesilurijskikh rifovykh biot (Ecological features of Late Silurian reef biota). Sreda I Zhizn'v geologicheskom proshlom. Proceedings. Novosibirsk. pp. 49-50.

7. Antoshkina A. I., Soja C. M. 2006. Reef biota migration between Alaska, the Urals, and Salair allows Late Silurian reconstruction. GFF. V. 128, pp. 75-78.

8. Antoshkina A. I., Soja C. M., and White B. 2000. New data on the composition of a Ludlow reef in the Northern Urals, Russia. Pan-Arctic Palaeozoic Tectonics, Evolution of Basins and Fauna. Syktyvkar. Geoprint, pp. 22-26 (Ichthyolith Issue, Special Publication, 6).

9. Baarli B. G., Johnson M. E., and Antoshkina A. I. 2003. Silurian Stratigraphy and Paleogeography of Baltica. In E. Landing \& M. E. Johnson (eds.) Silurian Lands and Seas. Paleogeography Outside of Laurentia. New York State Museum Bulletin. V. 493, pp. 3-35.
10. Barclay W. J., Browne M. A. E., McMillan A. A., Pickett E. A., Stone P., and Wilby P. R. 2005 (eds.). The Old Red Sandstone of Great Britain. Geological Conservation Review Series. No. 31. Peterborough, U. K. Joint Nature Conservation Committee. 393 p.

11. Beranek L. P., van Staal C. R., Gordee S. M., McClelland W. C., Israel S., and Mihalynuk M. 2012. Tectonic significance of Upper Cambrian-Middle Ordovician mafic volcanic rocks in the Alexander terrane, Saint Elias Mountains, northwestern Canada. Journal of Geology. V. 120, pp. 293-314.

12. Beranek L. P., van Staal C. R., Gordee S. M., McClelland W. C., Israel S., and Mihalynuk M. 2013a. Detrital zircon $\mathrm{Hf}$ isotopic compositions indicate a northern Caledonian connection for the Alexander terrane. Lithosphere. V. 5, pp. 163-168.

13. Beranek L. P., van Staal C. R., Gordee S. M., McClelland W. C., Israel S., and Mihalynuk M. 2013b. Baltican crustal provenance for Cambrian-Ordovician sandstones of the Alexander terrane, North American Cordillera: Evidence from detrital zircon $\mathrm{U}-\mathrm{Pb}$ geochronology and $\mathrm{Hf}$ isotope geochemistry. Journal of the Geological Society. V. 170. pp. 7-18.

14. Blodgett R. B., Boucot A. J., Rohr D. M., and Pedder A. E. H. 2010. The Alexander terrane of Alaska - a displaced fragment of Northeast Russia? Evidence from SilurianMiddle Devonian megafossils and stratigraphy. Memoirs of the Association of Australasian Palaeontologists. V. 39, pp. 323339.

15. Blodgett R. B., Boucot A. J., Baranov V. V., and Rohr D. M. 2013. Sapelnikoviella santuccii, a new gypidulinid brachiopod genus and species from the Upper Silurian of Glacier Bay National Park \& Preserve, southeast Alaska. Memoirs of the Association of Australasian Palaeontologists. V. 44, pp. 65-72.

16. Blodgett R. B., Tainter A. W. and Rohr D. M. 2014. Alaska fossils of the month: The Siberian origin of the Alexander terrane of southeast Alaska. Newsletter of the Alaska Geological Society. V. 44 (5), pp. 5-8.

17. Boucot A. J., Blodgett R. B., and Rohr D. M. 2012. Strophatrypa, a new genus of Brachiopoda (Atrypidae), from Upper Silurian strata of the Alexander terrane, northeast Chichagof Island, Alaska. Bulletin of Geosciences. V. 87, pp. 261-267.

18. Clough J. G., Blodgett R. B. 1989. Silurian-Devonian algal reef mound complex of southwest Alaska. In Geldsetzer, H. H. J., James, N. P., Tebbutt, G. E. (eds.), Reefs Canada and Adjacent Areas. Canadian Society of Petroleum Geologists. Memoir. V. 13, pp. 404-407.

19. Cocks L. R. M., Torsvik T. H. 2010. The Palaeozoic geography of Laurentia and western Laurussia: A stable craton with mobile margins. Earth-Science Reviews. V. 106, pp. 1-51.

20. Colpron M., Nelson J. L. 2010. Chapter31. A Palaeozoic NW Passage and the Timanian, Caledonian and Uralian connections of some exotic terranes in the North American Cordillera. Geological Society. London. Memoirs. V. 35, pp. 463-484.

21. Corfu F., Gasser D., and Chew D. M. 2014. New perspectives on the Caledonides of Scandinavia and related areas: Introduction, in Corfu F., Gasser D., and Chew D. M., eds., New Perspectives on the Caledonides of Scandinavia and Related Areas. Geological Society. London. Special Publications. V. 390, pp. $1-8$.

22. de Frietas T.A., Brunton F., and Bernecker T. 1993. Silurian megalodont bivalves of the Canadian Arctic and Australia: Paleoecology and evolutionary significance. Palaios. V. 8. (5), pp. 450-464. 
23. Dobretsov N. L., Buslov M. M. 2007. Pozdnekembrijskoordovikskaya tektonika I geodinamika Tsentralnoj Azii (Late Cambrian-Ordovician tectonics and geodynamics of Central Asia). Geologiya I Geophysika. V. 48, pp. 71-82.

24. Ebbestad J. O. R., Frýda J., Wagner P., Horný R., Isakar M., Stewart S., Percival I., Bertero V., Rohr D. M., Peel J. S., Blodgett R. B. and Högström A. E. S. 2013. Biogeography of Ordovician and Silurian gastropods, monoplacophorans and mimospirids. In Harper D. A. T. and Servais T. (eds). Early Palaeozoic Biogeography and Palaeogeography. Geological Society. London. Memoirs V. 38 (1), pp. 199-220.

25. Gee D. G., Fossen H., Henriksen N., and Higgins A. K. 2008. From the Early Paleozoic platforms of Baltica and Laurentia to the Caledonide orogen of Scandinavia and Greenland. Episodes. V. 31, pp. 44-51.

26. Grove M., Gehrels G. E., Cotkin S. J., Wright J. E., and Zou H. 2008. Non-Laurentian cratonal provenance of Late Ordovician eastern Klamath blueschists and a link to the Alexander terrane. Geological Society of America. Special Paper. V. 438, pp. 223-250.

27. Johnson J. G., Boucot A. J. and Murphy M. A. 1976. Wenlockian and Ludlovian age brachiopods from the Roberts Mountains Formation of central Nevada University of California Publications in Geological Sciences. V. 105, pp. 1-102.

28. Jones B. 1981. Atrypoidea species from the Canadian Arctic islands. Canadian Journal of Earth Sciences. V. 1810. P. 1539-1561.

29. Kriz J., Blodgett R. B., and Rohr D. M. 2010. Silurian bivalvia from Chichagof Island, southeast Alaska (Alexander terrane). Bulletin of Geosciences. V. 86 (2), pp. 241-258.

30. Lawver L. A., Gahagan L. M., and Norton I. 2010. Chapter 5. Palaeogeographic and tectonic evolution of the Arctic region during the Palaeozoic. Arctic Petroleum Geology. Geol. Soc. London. Memoirs V. 35, pp. 61-77

31. Metelkin D. V., Vernikovsky V. A., and Kazansky A. Y. 2012. Tektonicheskaya evolyutsiya Sibirskogo paleokontinenta ot neoproterozoya do pozdnego mezozoya: paleomagnitnye dannye i reconstruktsiya (Tectonic evolution of Siberia paleocontinent from Neoproterozoic to Late Mezozoic: paleomagnetic data and reconstruction). Geologiya i Geophysika. V. 53, pp. 675-688.

32. Miller E. L., Kuznetsov N., Soboleva A., Udoratina O., Grove M. J., and Gehrels G. 2010. Baltica in the Cordillera? Geology. V. 39, pp. 791-794.

33. Paleobiology Database (Fossilworks: Gateway to the Paleobiology Database). http://fossilworks. org/?a=home

34. Pedder A. E. H. 2006. Zoogeographic data from studies of Paleozoic corals of the Alexander terrane, southeastern Alaska and British Columbia / Haggart J., Enkin R., and Monger, J. (eds.). Paleogeography of western North America: Constraints on Latitudinal Displacements. Geological Association of Canada. Special Paper. V. 46, pp. 29-57.

35. Pellegrini A. F. A., Soja C. M. and Chuluun M. 2015. Post-tectonic limitations on Early Devonian (Emsian) reef development in the Gobi-Altai region, Mongolia. Lethaia, V. 45, pp. 46-61.

36. Puchkov V. N. 2010. Geologiya Urala i Priuralya (aktualnye voprosy stratigrafii, tektoniki, geodinamiki i metallogenii) (Ural and Subural geology (problems of stratigraphy, tectonics, geodynamics and metallogeny). Ufa, DizainPoligrafServis, $240 \mathrm{p}$.

37. Riding R., Soja C. M. 1993. Silurian calcareous algae, cyanobacteria, and micro-problematica from the Alexander terrane, Alaska. Journal of Paleontology. V. 63, pp. 710-728.
38. Rigby J. K., Nitecki M. H., Soja C. M., and Blodgett R. B. 1994. Silurian aphrosalpingid sphinctozoans from Alaska and Russia. Acta Palaeontologica Polonica. V. 39, pp. 341391.

39. Rigby J. K., Rohr D. M., Blodgett R. B., and Britt B. B. 2008. Silurian sponges and some associated fossils from the Heceta Limestone, Prince of Wales Island, Southeastern Alaska. Journal of Paleontology. V. 82, pp. 91-101.

40. Rohr D. M., Blodgett R. B. 2008. Silurian gastropods from the Alexander Terrane, southeast Alaska. In Blodgett R. B., \& G. D. Stanley (eds.). The terrane puzzle: New perspectives on paleontology and stratigraphy from the North American Cordillera. Geological Society of America. Special Paper 442, pp. $51-61$.

41. Rohr D. M., Blodgett R. B., and Fryda J. 2008. Silurian gastropoda from southeastern and west-central Alaska. Journal of Paleontology 82 (3), pp. 604-610.

42. Sapelnikov V. P., Bogoyavlenskaya O. V., Mizens L. I., and Shuysky V. P. 1999. Silurian and Early Devonian benthic communities of the Ural-Tien Shan region. In: Boucot A. J. \& Lawson J. D. (eds). Paleocommunities: A Case Study from the Silurian and Lower Devonian. Cambridge University Press. pp. 510-544.

43. Sheehan P. M., Harris M. T. 1997. Upper OrdovicianSilurian macrofossil biostratigraphy of the eastern Great Basin, Utah and Nevada. U. S. Geological Survey Professional Paper 1579-C. pp. 89-121.

44. Skompski S. 2010. Paleobiogeographical significance of the Late Silurian micro-problematicum Tuxekanella Riding and Soja. Journal of Paleontology. V. 84, pp. 346-351.

45. Soja C. M. 1991. Origin of Silurian reefs in the Alexander terrane of southeastern Alaska. Palaios. Vol. 6, pp. 101-126.

46. Soja C.M. 1991. Silurian trace fossils in carbonate turbidites from the Alexander arc of southeastern Alaska. Ichnos. V. 1, pp. 173-181.

47. Soja C. M. 1994. Significance of Silurian stromatolitesphinctozoan reefs. Geology. V. 22, pp. 355-358.

48. Soja C. M. 2008. Silurian-bearing terranes of Alaska. In Blodgett R. B., Stanley G. D., Jr. (eds.). The terrane puzzle: New perspectives on paleontology and stratigraphy from the North American Cordillera. Geological Society of America. Special Paper. V. 442, pp 39-50.

49. Soja C. M., Antoshkina A. I. 1997. Coeval development of Silurian stromatolite reefs in Alaska and the Ural Mountains: implications for paleogeography of the Alexander terrane. Geology. V. 25, pp. 539-542.

50. Soja C. M., Antoshkina A. I. 2013. Terrein Aleksandra severoamerikanskikh kordil'er: kriticheskij analiz silurijsko-devonskoj paleogeographii (The Alexander terrane of North America Cordillera: critical analysis of Silurian-Devonian paleogeography). Litosphera. V. 4, pp. 3-21.

51. Soja C. M., Krutikov L. 2008. Provenance, depositional setting, and tectonic implications of Silurian polymictic conglomerates in Alaska's Alexander terrane. In Blodgett, R. B., Stanley, G. D., Jr. (eds.), The terrane puzzle: New perspectives on paleontology and stratigraphy from the North American Cordillera. Geological Society of America Special Paper. V. 442, pp. 63-75

52. Soja C. M., Minjin C., Myrow P., and Over D. J. 2010. Paleozoic paleoenvironmental reconstruction of the Gobi-Altai terrane, Mongolia. In de Wet A. P. \& Heister L. (eds.), Keck Geology Consortium. Proceedings of the 23r Annual Keck Research Symposium in Geology, pp. 182-199

53. Soja C. M., Mitchell M., Newton A. J., Vendetti J., Visaggi C., Antoshkina A. I., and White B. 2003. Paleoecology of 
sponge-?hydroid associations in Silurian microbial reefs. Palaios. V. 18 , pp. 225-235.

54. Soja C. M., Riding R. Silurian microbial communities from the Alexander terrane, Alaska // J. Paleontology, 1993. V. 63 , pp. $728-738$.

55. Soja C. M., White B. 2016. Lacustrine deposits in the Karheen Formation fortify links between Alaska's Alexander terrane and the Old Red Sandstone continent in the Late Silurian-Early Devonian. Journal of Sedimentary Research. in press.

56. Soja C. M., White B., Antoshkina A., Joyce S., Mayhew L., Flynn B., and Gleason A. 2000. Development and decline of a Silurian stromatolite reef complex, Glacier Bay National Park, Alaska. Palaios. V. 15, pp. 273-292.

57. Till A. B., Dumoulin J. A., and Bradley D. C. 2010. Paleogeographic reconstruction of the Arctic Alaska-Chukotka terrane based on zircon and paleontologic data from Seward
Peninsula. Geological Society of America Abstracts with Programs. V. 42 (5), pp. 573

58. van Staal C. R., Beranek L., Israel S. A., McClelland W. C., Mihalynuk M. G., Nelson J. A., and Joyce N. 2010. New data and ideas on the Paleozoic-Triassic evolution of the Insular Superterrane of the North American Cordillera. Geological Society of America. Abstracts with Programs. V. 42 (5), pp. 574

59. Yolkin E. A., Sennikov N. V., Bakharev N. K., Izokh N. G., and Klets A. G. 2003. Silurian paleogeography along the southwest margin of the Siberian continent: Altai-Sayan folded area. In Landing, E., Johnson, M. E. (eds.), Silurian Lands and Seas: Paleogeography Outside of Laurentia. New York State Museum Bulletin. V. 493, pp. 299-321.

60. Zonenshain L. P., Kuzmin M. I., and Natapov L. M. 1990. Geology of the USSR: A plate-tectonic synthesis. AGU Geodynamic Series. V. 21, 1-242 pp. 